\title{
pnmbalina
}

(8)

\section{Live fuel moisture content: variability, predictability and impact on fire behavior and activity} \author{
Autor(es): $\quad \begin{aligned} & \text { Nicolas, Martin-StPaul; Julien, Ruffault; Pimont, François; Dupuy, Jean- } \\ & \text { Luc }\end{aligned}$
}

Publicado por: Imprensa da Universidade de Coimbra

URL persistente:

URI:http://hdl.handle.net/10316.2/44543

DOI:

DOI:https://doi.org/10.14195/978-989-26-16-506_26

Accessed : $\quad$ 26-Apr-2023 12:54:13

A navegação consulta e descarregamento dos títulos inseridos nas Bibliotecas Digitais UC Digitalis, UC Pombalina e UC Impactum, pressupõem a aceitação plena e sem reservas dos Termos e Condições de Uso destas Bibliotecas Digitais, disponíveis em https://digitalis.uc.pt/pt-pt/termos.

Conforme exposto nos referidos Termos e Condições de Uso, o descarregamento de títulos de acesso restrito requer uma licença válida de autorização devendo o utilizador aceder ao(s) documento(s) a partir de um endereço de IP da instituição detentora da supramencionada licença.

Ao utilizador é apenas permitido o descarregamento para uso pessoal, pelo que o emprego do(s) título(s) descarregado(s) para outro fim, designadamente comercial, carece de autorização do respetivo autor ou editor da obra.

Na medida em que todas as obras da UC Digitalis se encontram protegidas pelo Código do Direito de Autor e Direitos Conexos e demais legislação aplicável, toda a cópia, parcial ou total, deste documento, nos casos em que é legalmente admitida, deverá conter ou fazer-se acompanhar por este aviso.

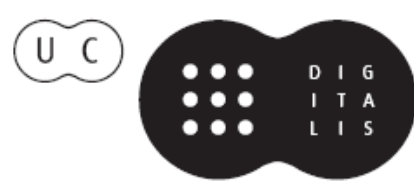




\section{ADVANCES IN}

\section{FOREST FIRE RESEARCH}

\section{8}

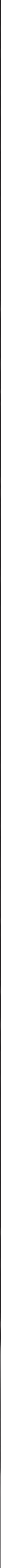




\title{
Live fuel moisture content: variability, predictability and impact on fire behavior and activity
}

\author{
Martin-StPaul Nicolas ${ }^{1 *}$, Ruffault Julien ${ }^{2}$, François Pimont ${ }^{1}$, Jean-Luc Dupuy ${ }^{1}$ \\ ${ }^{1}$ URFM INRA. 84914 Avignon, France, \\ \{nicolas.martin@inra.fr*,francois.pimont@inra.fr,jean-luc.dupuy@inra.fr\} \\ ${ }^{2} I M B E$, Aix Marseille Université, CNRS, IRD, Avignon Université, Marseille, France, \\ \{julien.ruff@gmail.com\}
}

\begin{abstract}
Live Fuel Moisture Content (LFMC) - the ratio of water mass to the dry mass of live fuel - is a critical factor of fire behavior and hazard. This parameter is largely controlled by weather conditions and is affected by climate changes. There is therefore an increasing need, to understand its variability, to improve its predictability and its impact on fire behavior and activity. This would enhance the development of tools for operational fire risk management and wildfire research. Here we compile several recent findings regarding these issues, most of them were based on the French LFMC database collected for operational purposes and containing more than 20,000 measurement dates during 22 fire seasons on 30 sites and 25 species distributed over the French Mediterranean. First we evaluated the predictability of LFMC by fitting linear relationships between LFMC and various daily empirical drought indices (Drought Code=DC, Keetch-Byram Drought Index=KBDI, Dead Moisture Code=DMC) and a water balance model describing the Relative Water Content of the soil (RWC). We found a limited explanatory power of the drought indices based on climate only due to large differences between sites and species. This support the view that predictions can be improved by accounting for stand and species specific parameters by developing more process-based approaches. The RWC model is a first step toward this direction, and can account for stand level parameterization of soil properties and leaf area index of the vegetation if data are available. To account for species specific traits involved in plant dehydration, we suggest an adaptation of a plant hydraulic model to simulate LFMC response to water potential according to plant hydraulic traits. This is promising with regard to the development of a fully-mechanistic approach of the prediction of LFMC, which would include the responses of both plant and soil. Second, we used an existing dataset reporting shrub fire experiments to investigate the response function of fire rate of spread (ROS) to LFMC. We found a very significant effect of LFMC below $100 \%$. However, because most LFMC values in the ROS database are higher than those prevailing in the French database, large uncertainties in ROS estimation were obtained below LFMC of ca. 70\%. Finally, we explored the relationship between and fire occurrence using a French database of fire activity and the French LFMC database. We found that the response of the fire occurrence of more than 1 ha was very similar to the response of rate of spread. Our global approach drawing on long-term field LFMC data constitutes an important step forward in weaving the mechanistic links between climate, vegetation functioning and fire activities.
\end{abstract}

Keywords: LFMC, fire occurrence; drought index;

\section{Introduction}

Live Fuel Moisture Content (LFMC) - the ratio of water mass to the dry mass of live fuel - is increasingly recognized as a critical factor of fire behavior (Rossa et al. 2016) and hazard (Dennison and Moritz 2009; Nolan et al. 2016; Ruffault et al. 2018). This fuel parameter is obviously affected by drought and thus climate change, but its dynamic remains poorly understood and predicted. 
While field measurement remains the reference method for evaluating LFMC, it is generally limited for obvious practical constraints. Remote sensing is an appealing alternative to field measurements but requires extensive calibration and validation (Yebra et al. 2013). Another widespread approach is the use of empirical relationships between meteorological drought indices (Drought Code, KeetchByramDrought Index, etc.) and LFMC (Viegas et al. 2001) (Viegas et al., 2001), which enables forecast and projection, since such indices implement simple functions of basic daily weather data (temperature, precipitation, etc.).

A 20,000 multispecies and multisite dataset of LFMC measurements in Mediterranean France over 20 years has recently been released (referred to as "RH" for "Réseau Hydrique", Martin-StPaul et al. 2018). This dataset provides new opportunities to increase knowledge regarding 1) the predictability of LFMC through meteorological drought indices and remote sensing products; 2) The basis for a mechanistic modelling of LFMC, which could account for both soil and vegetation properties; 3) its impact on fire activity, through comparisons between LFMC dynamics and actual fire activity.

In the present study, we address these three points, with the exception of remote sensing predictability, which has already been evaluated on this dataset (Fan et al. 2018). The basis In order to evaluate the impact of LFMC on fire behavior, we also use the shrub fire experiment dataset collected in Anderson et al. (2015) to assess the response of the fire rate of spread (ROS) to LFMC.

\section{Live Fuel Moisture predictability and variability}

\subsection{Empirical indices to predict Live Fuel Moisture Content}

We evaluated the predictability of LFMC by fitting linear relationships between LFMC and various empirical drought indices (Drought Code=DC, Keetch-Byram Drought Index=KBDI, Dead Moisture Code $=$ DMC) and a process-based water balance model describing the Relative Water Content of the soil (RWC). Climatic data required (including temperature, rainfall, radiation, relative humidity) were extracted for each site from the French reanalysis SAFRAN. The species were classified in two groups according to their seasonal variability: high and low responding species. We found that the performance was similar for all drought indices, with RMSE on the order of $18 \%$ and determination coefficients on the order of 0.3 (Figure 1). As pointed out in Yebra et al. (2013), such an error is too large for operational and research purposes, as the ignition probability corresponding to this error might range from low to high levels (from 19-60\%). Most of the factor of variability were due to site and species differences (Ruffault et al. under review)

Those results suggest that empirical drought indices should be used with caution for LFMC prediction and that such indices could probably be improved, using more mechanistic approaches that could account for site other than climate and species properties (Ruffault et al. under review). RWC is a first step toward this direction, but requires adequate parameterization of soil properties and leaf area index of the vegetation. We are currently consolidating a large database of soil properties and leaf area index for the different RH site where LFMC is currently measured in the French Mediterranean. This will help to elucidate to what extent soil and LAI contribute to defining LFMC dynamics during drought. 

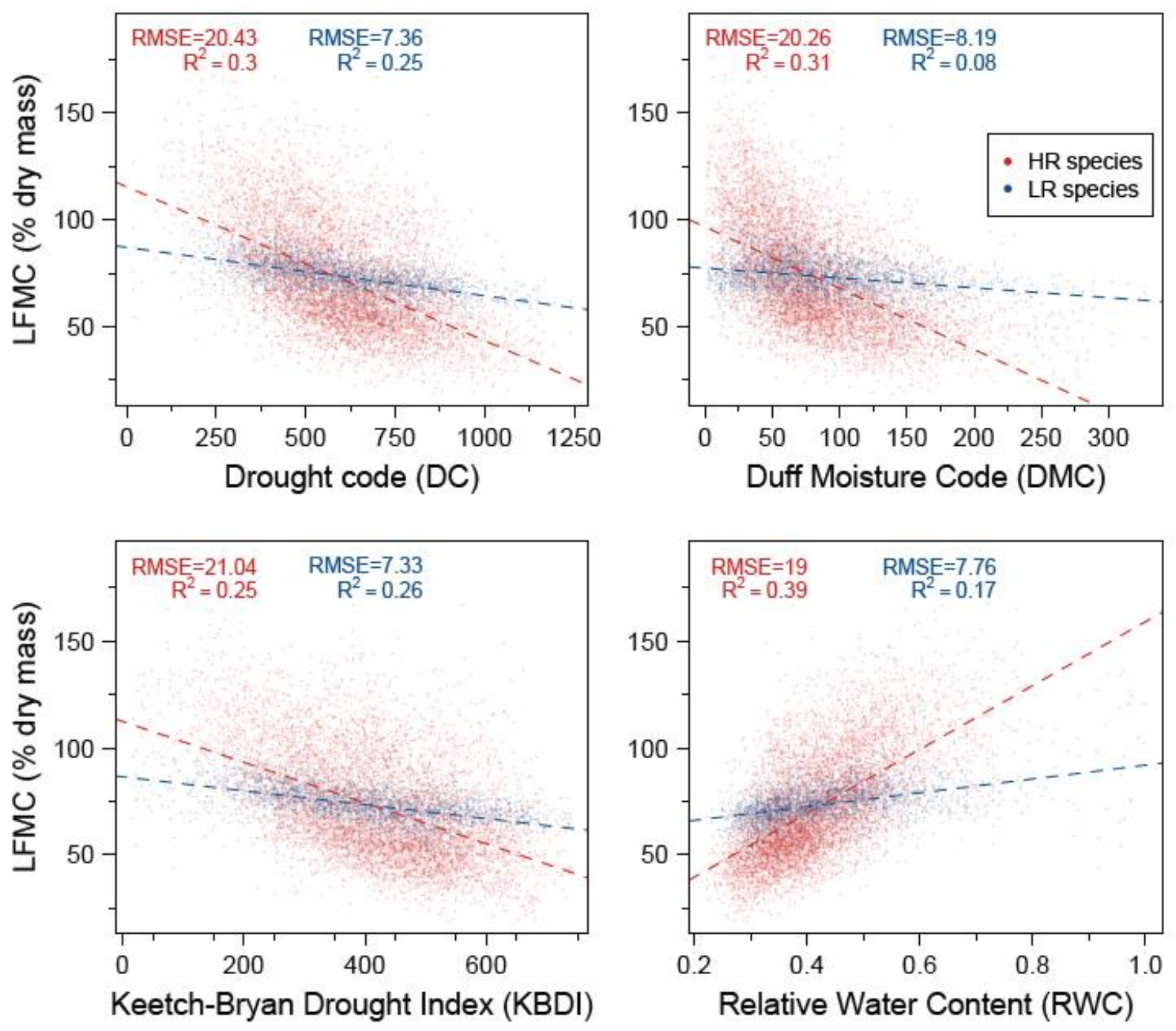

Figure 1 - Linear models between live fuel moisture content (LFMC) and different drought indices (DC, DMC, KDBI and $\left.R W C_{H}\right)$ for two different groups of species: High responding $(H R)$ and Low responding (LR) species. LFMC was measured during the fire season on 20 different sites for the period from 2000 to 2013.

\subsection{A physiological hydraulic basis for predicting species dynamics of LFMC}

We found that the predictability of LFMC including the low and high responding strategies- were linked to certain physiological traits related to plant hydraulic and plant regulation of water potential. This suggests that the physiology of water transport in plants, namely plant hydraulic, can provide insights regarding LFMC response to drought. In this context, we suggest a mechanistic framework to derive LFMC from plant water potential $(\psi, \mathrm{MPa})$. This framework is based on the plant hydraulic model SurEau presented in (Martin-StPaul et al. 2017). SurEau simulates two processes involved in plant desiccation: (i) the dehydration of the living cells (symplastic tissue) giving the relative water content of the symplast (RWCs) and (ii) the cavitation of the xylem (apoplastic tissue) giving the relative water content of the apoplast (RWCa). Both values can then be used to predict LFMC, if the specific dry mass content and the apoplastic fraction of the tissue considered are known. Fig. 2 illustrates a typical dynamic of symplastic and apoplastic RWC as well as LFMC as a function of plant water potential, for a set of species-specific parameters indicated in the legend. Further details about the equations and parameters can be found in the description of the SurEau model in Martin-StPaul et al (2017). 


\section{LFMC vs water potential}

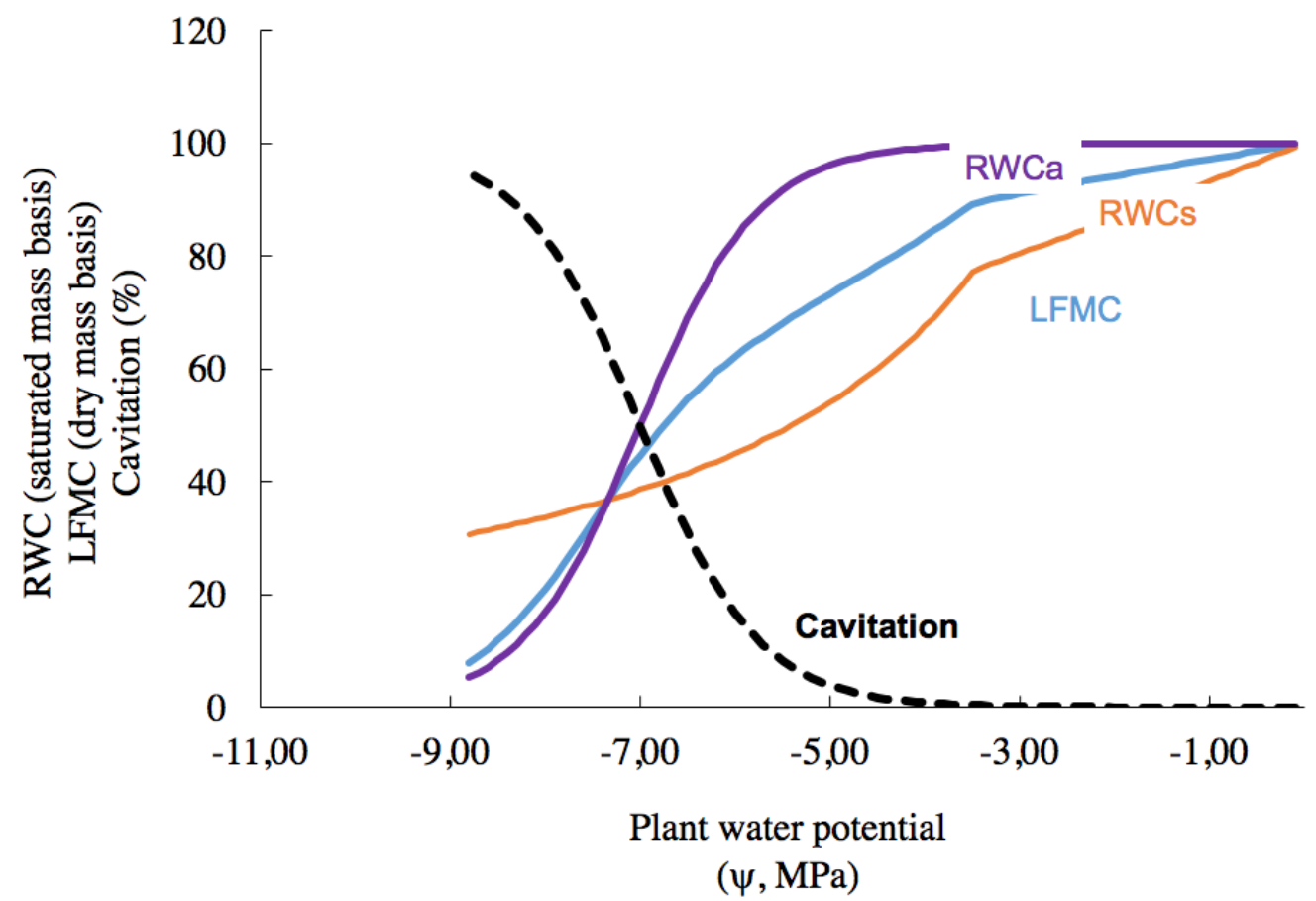

Figure 2 - Theoretical response of LFMC to plant water potential simulated with SurEau describing the dynamic of relative water content in both the symplastic compartment (RWCs) and the apoplastic compartment (RWCa). The dynamic of cavitation is shown in black. For these simulations we used a cavitation resistance (taken as the water potential causing $50 \%$ cavitation) of $-7 \mathrm{MPa}$, a turgor loss point of $-3.5 \mathrm{MPa}$, a leaf dry matter content of $500 \mathrm{mg} / \mathrm{g}$, and an apoplastic fraction of 0.4. Further details about the equations and parameters can be found in the description of the SurEau model in Martin-StPaul et al (2017).

\section{Live Fuel Moisture impact on fire behavior}

In this subsection, we use a shrub fire experiment dataset (Anderson et al. 2015) to fit a model for rate of spread (ROS) as a function of LFMC. The model is the following generalized additive model (GAM, Hastie et al. 2009):

$$
R O S=a U^{b} e^{-c D F M C} H^{d} S(L F M C)
$$

where $\mathrm{s}$ is smooth function. The model fit, using a "log" link and assuming a gamma distribution of the residuals, is described in details in Pimont et al. (2018a).

The response of ROS to LFMC is a multiplicative function showing a strong increase of fire behavior when LFMC is below 100\%, but negligible above it (Fig. 2). The green, orange and red arrows show the different ROS increases (in \%) associated with the three thresholds used by French fire prevention and fighting managers. Our analysis shows that these thresholds effectively correspond to strong increase in fire behavior. However, the range of the confidence intervals strongly increases below $67 \%$, as the experimental fires were hold in LFMC conditions above 67\% (between 67 and 256 $\%)$. 


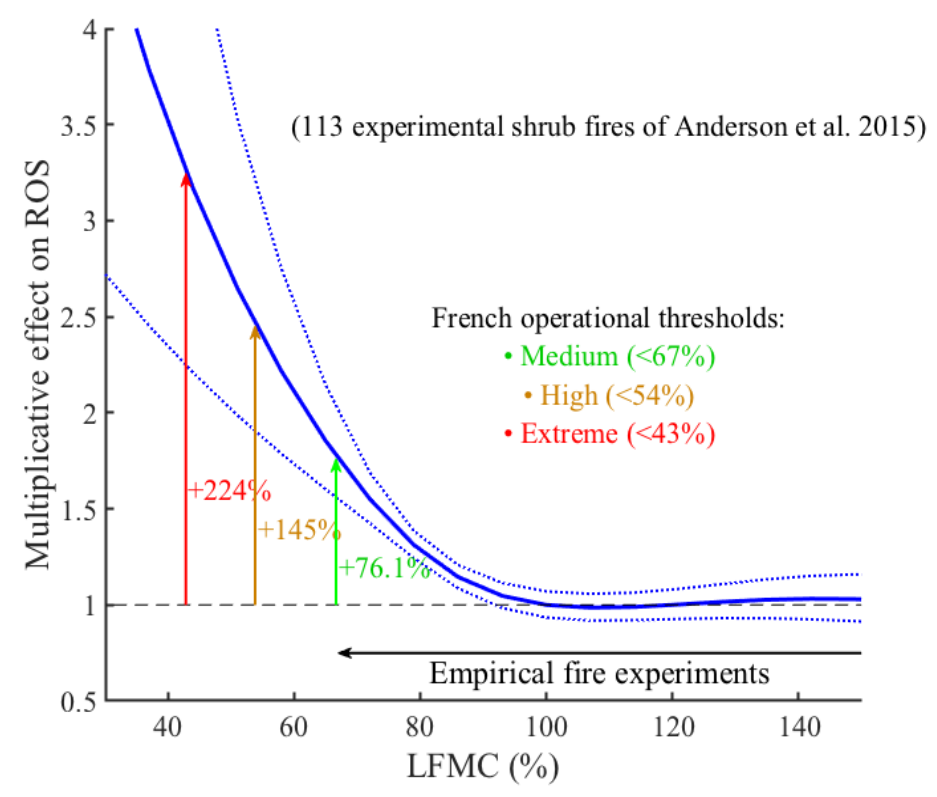

Figure 3 - Response of fire rate of spread as a function of LFMC, derived from Eq. 1, fitted over the fire experiments described in Anderson et al. (2015). A strong increase in ROS is observed below 100\%, even if the confidence intervals strongly increase below $67 \%$ because of the lack of experimental data in this range.

Comparing the range of LFMC in fire experiments and in the $\mathrm{RH}$ dataset confirms this strong discrepancy between LFMC in fire experiments and the conditions prevailing during the actual fire season.

\section{Live Fuel Moisture impact on fire activity}

We used the LFMC dataset and a French database reporting fire activity in order to evaluate how LFMC relates to fire occurrence, based on fires that occurred at less than $10 \mathrm{~km}$ to the LFMC measurement sites. In order to study how fire activity relates to LFMC, we first used the approach of Dennison and Moritz (2009), but found that the method was very sensitive to the fire frequency distribution (Pimont et al. 2018b). Instead, we used a GAM model to study the response function for fire activity to LFMC in an approach derived from (Preisler et al. 2004). We first fitted the number of fires larger than 1 ha $\left(\mathrm{N}_{>1 \text { ha }}\right)$ as a function of LFMC, using a quasi Poisson family and a "log" link.

$$
\mathrm{N}_{>1 \text { ha }}=\mathrm{S}_{\mathrm{f}} \mathrm{s}(\mathrm{LFMC}) \text { Site }
$$

where $\mathrm{s}$ is smooth function, $\mathrm{S}_{\mathrm{f}}$ is the forest area in $10 \mathrm{~km}$ buffer zone around the LFMC measurement sites (in which fires were observed) and "Site" a factor to account for an eventual effect of the LFMC sampling location on fire density. Figure 4a represents the multiplicative response to LFMC of the number of fire larger than $1 \mathrm{ha}$, in a similar manner than Fig. 3. Interestingly, the shape of this response function, as well as its magnitude was very similar to the one reported for fire behavior on a completely different dataset and at a different scale. 

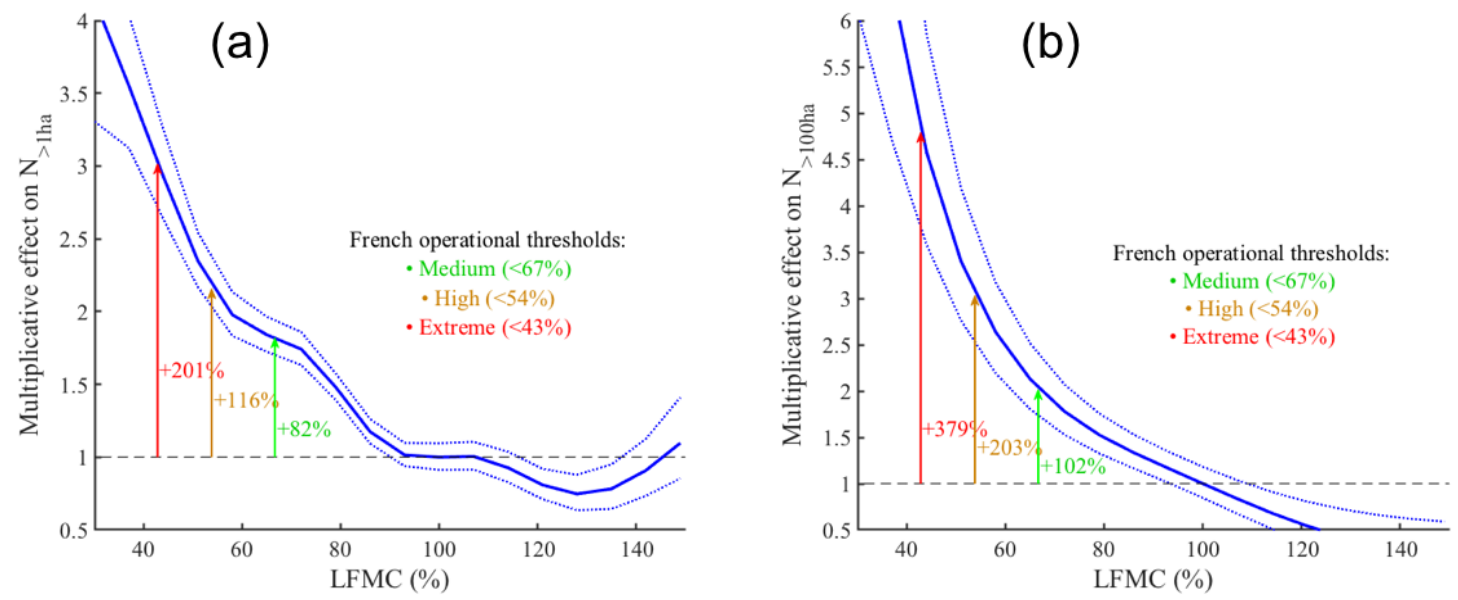

Figure 4 - (a) Response of the number of fires larger than 1ha as a function of LFMC, derived from Eq. 2, fitted over the $\mathrm{RH}$ dataset. A strong increase in fire number is observed below 100\%, exhibiting a response function very similar to the one of the ROS (Fig. 2). (b) Response of the number of fires larger than 1ha as a function of LFMC, as in Fig 3. The shape of the curve is sharper than for the $>1$ ha fires and still decay below $100 \%$.

We applied the same approach to the number of fires larger than 100ha $\left(\mathrm{N}_{>100 \mathrm{ha}}\right)$. However, the dataset is to sparse in this context to use the quasi binomial distribution and to account for the site effect. The model fit which assumes the basic binomial distribution (which does not account for over dispersion of the fire numbers, and hence might underestimate the confidence intervals) is shown in Fig. 4b.

The response function was much sharper than the one of the fire behavior and the number of fires larger than 1ha, which can be considered as an evidence of a stronger effect of LFMC on large fires. Also the effect of LFMC did not saturate below $100 \%$, suggesting that the probability to get such a large fire is much lower in humid conditions than in standard "LFMC $=100 \%$ " conditions.

\section{Discussion and conclusion}

This work presents new insights regarding the variability, predictability, physiological drivers and impact of LFMC on fire hazard based on extensive analysis applied to a large LFMC dataset. First, the variability between sites and species considerably limit the accuracy of drought indices. Comparison with calibration of remote sensing products suggest that the accuracy is relatively similar (Fan et al., 2018).

Improvements of LFMC modelling is nevertheless possible by accounting for site specific parameters in water balance models (e.g. soil water capacity and leaf area index) and species traits driving desiccation dynamic through plant hydraulic model (cavitation resistance, turgor loss). Our analyses also suggest that LFMC modelling can be significantly improved in the future on the basis of ecophysiological models (Ruffault et al. under review) which account for soil and vegetation properties, which is in line with a recent publication (Jolly and Johnson 2018). Here we suggested the use of the SurEau model for plant hydraulics (Martin-StPaul et al., 2017) to simulate LFMC with a mechanistic approach including traits. A major advantage of this approach is that is can be readily applied to a large variety of species thanks to the emergence of large databases of pressure volume curves and vulnerability curve to cavitation (Bartlett et al. 2012; Choat et al. 2012; Martin-StPaul et al. 2017). Ongoing research aims at coupling this approach to a water budget model (Ruffault et al. 2013) and to validate the approach over LFMC measurements in situ, thanks to the RH database and the ongoing data acquisition of complementary data (LAI, soil depth, weather data). However, there are still important limitations and research needs both in terms of data and model structure. For 
instance, the prediction of plant water potential and leaf shedding due to drought is not straightforward (Choat et al. 2018). Furthermore, accounting for phenology and decoupling the effects of water status from seasonal dry matter changes would likely strengthen these studies (Jolly et al. 2014).

The reanalyze of the empirical shrub fire dataset previously collected shows that the effect of LFMC on fire behavior is much stronger than previously estimated (Anderson et al. 2015), especially in the range below $100 \%$. Unfortunately, there is still a lack of empirical data in dry conditions corresponding to high and extreme fire sensitivity (Fig. 2), so that the confidence intervals are very large in this range. This argues for field experiments closer to the actual fire conditions, even if such experiments would be clearly very demanding for economic and safety reasons.

The comparison between the $\mathrm{RH}$ database and the fire database shows that fire occurrence is strongly dependent on LFMC. Fires of more than 1 ha exhibit a response to LFMC which is very similar to fire spread, which would suggest that fires can reach 1 ha only when they spread fast enough to be caught out by fire fighters. Larger fires are even more strongly determined by LFMC suggesting a fire frequency on the order of 5 times higher when LFMC is shifted from $100 \%$ to $43 \%$. It would be even 10 times higher when shifting from $120 \%$.

Most of the large-scale evidences of link between LFMC and fire activities were obtained through remote sensing and drought indices, which have shown to be limited in their ability to predict LFMC (Ruffault et al. 2018). Our on-going study of the influence of LFMC on fire behavior and activity from a local scale results in a better understanding of the role of LFMC.

\section{References}

Bartlett MK, Scoffoni C, Sack L (2012) The determinants of leaf turgor loss point and prediction of drought tolerance of species and biomes: A global meta-analysis. Ecology letters 15, 393-405. doi:10.1111/j.1461-0248.2012.01751.x.

Choat B, Brodribb TJ, Brodersen CR, Duursma RA, López R, Medlyn BE (2018) Triggers of tree mortality under drought. Nature 558, 531-539. doi:10.1038/s41586-018-0240-x.

Choat B, Jansen S, Brodribb TJ, Cochard H, Delzon S, Bhaskar R, Bucci SJ, Feild TS, Gleason SM, Hacke UG, Jacobsen AL, Lens F, Maherali H, Martínez-Vilalta J, Mayr S, Mencuccini M, Mitchell PJ, Nardini A, Pittermann J, Pratt RB, Sperry JS, Westoby M, Wright IJ, Zanne AE (2012) Global convergence in the vulnerability of forests to drought. Nature 491, 752-755. doi:10.1038/nature11688.

Dennison PE, Moritz MA (2009) Critical live fuel moisture in chaparral ecosystems: A threshold for fire activity and its relationship to antecedent precipitation. International Journal of Wildland Fire 18, 1021-1027. doi:10.1071/WF08055.

Fan L, Wigneron JP, Xiao Q, Al-Yaari A, Wen J, Martin-StPaul N, Dupuy JL, Pimont F, Al Bitar A, Fernandez-Moran R, Kerr YH (2018) Evaluation of microwave remote sensing for monitoring live fuel moisture content in the Mediterranean region. Remote Sensing of Environment 205, 210-223. doi:10.1016/j.rse.2017.11.020.

Hastie T, Tibshirani R, Friedman J (2009) 'The Elements of Statistical Learning.' (Springer New York: New York, NY) doi:10.1007/b94608.

Jolly WM, Hadlow AM, Huguet K (2014) De-coupling seasonal changes in water content and dry matter to predict live conifer foliar moisture content. International Journal of Wildland Fire 23, 480-489. doi:10.1071/WF13127.

Jolly WM, Johnson DM (2018) Pyro-Ecophysiology: Shifting the Paradigm of Live Wildland Fuel Research. Fire 1, 8. doi:10.3390/fire1010008. 
Martin-StPaul N, Delzon S, Cochard H (2017) Plant resistance to drought depends on timely stomatal closure (H Maherali, Ed.). Ecology Letters 1-23. doi:10.1111/ele.12851.

Martin-StPaul N, Pimont F, Dupuy JL, Rigolot E, Ruffault J, Fargeon H, Cabane E, Duché Y, Savazzi R, Toutchkov M (2018) Live fuel moisture content (LFMC) time series for multiple sites and species in the French Mediterranean area since 1996. Annals of Forest Science 75, doi:10.1007/s13595-018-0729-3.

Nolan RH, Boer MM, Resco de Dios V, Caccamo G, Bradstock RA (2016) Large-scale, dynamic transformations in fuel moisture drive wildfire activity across southeastern Australia. Geophysical Research Letters 43, 4229-4238. doi:10.1002/2016GL068614.

Pimont F, Ruffault J, Martin-StPaul N, Dupuy JL (2018b) Why is the effect of live fuel moisture content on fire rate of spread underestimated in field experiments in shrublands? Submitted to International Journal of Wildland Fire.

Pimont F, Ruffault J, Martin-StPaul N, Dupuy JL (2018b) A cautionary note regarding the use of cumulative burnt areas for the determination of fire danger index breakpoints. Under review in International Journal of Wildland Fire.

Preisler HK, Brillinger DR, Burgan RE, Benoit JW (2004) Probability based models for estimation of wildfire risk *. International Journal of Wildland Fire 13, 133. doi:10.1071/WF02061.

Rossa CG, Veloso R, Fernandes PM (2016) A laboratory-based quantification of the effect of live fuel moisture content on fire spread rate. International Journal of Wildland Fire 25, 569. doi:10.1071/WF15114.

Ruffault J, Curt T, Martin-StPaul NK, Moron V, Trigo RM (2018) Extreme wildfire events are linked to global-change-type droughts in the northern Mediterranean. Natural Hazards and Earth System Sciences 18, 847-856. doi:10.5194/nhess-18-847-2018.

Ruffault J, Martin-StPaul NK, Rambal S, Mouillot F (2013) Differential regional responses in drought length, intensity and timing to recent climate changes in a Mediterranean forested ecosystem. Climatic Change 117, 103-117. doi:10.1007/s10584-012-0559-5.

Viegas DX, Piñol J, Viegas MT, Ogaya R (2001) Estimating live fine fuels moisture content using meteorologically-based indices. International Journal of Wildland Fire 10, 223-240. doi:10.1071/WF01022.

Yebra M, Dennison PE, Chuvieco E, Riaño D, Zylstra P, Hunt ER, Danson FM, Qi Y, Jurdao S (2013) A global review of remote sensing of live fuel moisture content for fire danger assessment: Moving towards operational products. Remote Sensing of Environment 136, 455-468. doi:10.1016/j.rse.2013.05.029. 